\title{
Dissolved organic carbon in water fluxes of Eucalyptus grandis plantations in northeastern Entre Ríos Province, Argentina
}

\author{
Carbono orgánico disuelto en flujos hídricos de plantaciones de Eucalyptus grandis \\ del noreste, provincia de Entre Ríos, Argentina
}

\author{
Natalia Tesón $^{\text {a,b }}{ }^{\text {, Víctor H Conzonno }}{ }^{\text {a,c*, }}{ }^{\text {, Marcelo F Arturi }}{ }^{\text {a }}$, Jorge L Frangi a* \\ *Autor de correspondencia: ${ }^{a}$ Universidad Nacional de La Plata, Facultad de Ciencias Agrarias, \\ Laboratorio de Investigación de Sistemas Ecológicos y Ambientales (LISEA), La Plata, Argentina, \\ Diagonal 113, No 469, (1900) La Plata, Argentina, tel.: + 54221427 1442, jfrangi@agro.unlp.edu.ar \\ ${ }^{\mathrm{b}}$ INTA, EEA Concordia, Entre Ríos, Argentina. \\ ${ }^{\mathrm{c}}$ CONICET, Argentina.
}

\begin{abstract}
SUMMARY
Water fluxes in tree plantations and other ecosystems carry dissolved organic carbon (DOC) provided by atmospheric inputs, autotrophic and heterotrophic metabolisms and from the lysis of dead material. These compounds may be colorless or provide a yellow-to-brown color to water and may also absorb visible light due to the presence of chromophores in the chemical structure. Concentration and composition of DOC and DOC annual flux in water pathways of a Eucalyptus grandis plantation were studied in Entre Ríos, Argentina. Samples of bulk precipitation, throughfall, stemflow, litter lixiviation, surface runoff and water table were analyzed for DOC concentration and color (optical density). Regression analyses for DOC concentration vs water fluxes intensity and for DOC concentration vs color were done. A DOC circulation model was calculated using available information on water budgets fluxes. Results showed that molecular features, values and range of DOC concentrations varied among fluxes, which may be explained by factors and processes influencing water gains and losses and by composition and availability of organic matter that may be dissolved in water in contact with biomass, necromass, soil and subsoil. Regression parameters from DOC concentration vs optical density were useful for DOC chemical composition analyses and interpretation of DOC changes. Annual circulation of DOC (in $\mathrm{kg} \mathrm{ha}^{-1} \mathrm{year}^{-1}$ ) showed that atmospheric contribution is low (ca. 30), aboveground biomass lixiviation is about 3-4 times the atmospheric input (126.7 to 101.4 ), and inputs to mineral soil (374.4 to 348.0 ) came mainly (74 to $78 \%$ ) from litter lixiviation.
\end{abstract}

Key words: DOC concentration, water fluxes, color, Eucalyptus grandis plantations, Entre Ríos (Argentina).

\section{RESUMEN}

Los flujos de agua en los ecosistemas transportan carbono orgánico disuelto (COD) de los aportes atmosféricos, el metabolismo autotrófico y heterotrófico y la lisis de materia muerta. Estos compuestos pueden ser incoloros o coloreados, y absorber luz visible debido a la presencia de cromóforos. Se estudiaron la concentración, composición y flujo anual de COD en las vías hídricas de una plantación de Eucalyptus grandis, Entre Ríos, Argentina. Se determinó la concentración de COD y color (densidad óptica) en muestras de agua de precipitación bruta, trascolación, flujo caulinar, lixiviación del mantillo, escurrimiento superficial y napa freática. Se realizaron regresiones COD vs flujo hídrico y COD vs color. Se modeló la circulación de COD. Las características moleculares y los valores y rangos de concentración de COD variaron entre flujos hídricos que se explicarían por factores y procesos que influencian las ganancias y pérdidas de agua y la composición y disponibilidad de materia orgánica que puede disolverse en aguas en contacto con la biomasa, la necromasa, los horizontes del suelo y el subsuelo. Los parámetros de regresión COD vs color resultaron útiles para analizar la composición del COD e interpretar los cambios en COD en las aguas. La circulación anual de COD muestra que la contribución $\left(\mathrm{kg} \mathrm{ha}^{-1} \mathrm{año}^{-1}\right)$ atmosférica es baja (ca. 30), el lixiviado de la biomasa aérea es alrededor de 3-4 veces el suministrado por la atmósfera $(126,7$ a 101,4) y el ingreso al suelo $(374,4$ a 348,0) deriva principalmente (74 a $78 \%$ ) de la lixiviación del mantillo.

Palabras clave: concentración de COD, flujos hídricos, color, plantaciones de Eucalyptus grandis, Entre Ríos (Argentina).

\section{INTRODUCTION}

Carbon, the main component of living tissues, is originally fixed through photosynthesis. It is part of the organic compounds that are energy sources and structural components; it also participates of biological, physiological and ecological processes of living beings and ecosystems. Moreover, carbon integrates the necromass, soil organic matter and deposits that, in the long term, give place to fossil fuels. Through oxidation-reduction processes, carbon reacts with other mineral elements, forms distinct molecules and substances, gives place to mineral cycles and links the 
living and inert layers of the Earth. For a comprehensive account of these issues and those in the following paragraph, see for example Harmon et al. (1986), Kimmins (1997), Schlesinger (1997), Lambers et al. (1998), Chapin III et al. (2002), Frangi et al. (2004).

Carbon cycling studies in forests require taking into account its concentration and content in biomass, necromass and soil, as well as in circulation in fluxes of biochemical, biogeochemical and geochemical cycles. The forest water pathways of input, internal circulation and output carry dissolved organic carbon (DOC) that is part of the last two cycle types mentioned. In natural systems, DOC originates from autotrophic and heterotrophic metabolic activities and the lysis of dead material. As a result, extra-cellular labile compounds, such as peptides, carbohydrates, fatty acids and their derivatives of relatively low molecular weight, are incorporated into the liquid phase. On the other hand, the degradation of the lignin present in vascular plants supplies dissolved high molecular refractory compounds of aromatic character, such as humic substances during the humification process. Negative charges, associated with the presence of carboxylic and phenolic groups in these substances integrating the DOC, play a role in the ionic balance of the solutions according to Laclau et al. (2003) found in savanna and Eucalyptus spp. plantations. Hence, the importance of DOC is related to the magnitude of the carbon flux. Because of the organic anion property, cation transport and distribution in ecosystems is extended. These compounds, that impart a yellow-to-brown color to water, also absorb UV-visible light due to the presence of chromophores -groups of atoms which contain unsaturated bonds shaped like aromatic rings in the molecular structure. The absorption property has been used, for several decades, for the evaluation of DOC in terms of chemical oxygen demand (De Haan et al. 1982, Conzonno and Fernández Cirelli 1988, 1995, 1996, Scapini et al. 2011) and for the characterization of humic substances (De Haan 1972, Chen et al. 1977, Ghosh and Schnitzer 1979, Conzonno and Fernández Cirelli 1995, Scapini et al. 2008).

The interest is focused in Eucalyptus grandis W. Hill ex Maiden, the species of the genera presented the most extensive area of plantations in Argentina, at a locality characterized by eucalyptus wood production. Hypotheses are: 1) water in contact with the atmosphere, tree foliage, branches, trunk and soil horizons changes the concentration and quality of DOC in the corresponding water flux. Moreover, the processes of DOC production and transformation that happen on each surface in contact with water are affected by the gains and losses of water in each flux. Moreover, these changes may be observed at ecosystem level in DOC annual circulation in water fluxes. 2) As organic compounds may show color in the visible range, and color depends on molecular weight and polymerization degree, there are significant differences in chemical composition among fluxes. The objectives are: 1) to relate the content of DOC to color in water fluxes samples obtained from plantations of $\mathrm{Eu}-$ calyptus grandis at rotation end, 2) to find mathematical functions for DOC estimation needed for carbon balance applications in these plantations, using color as the independent variable, 3) to analyze regression parameters in order to evaluate, qualitatively and quantitatively, organic compounds in forest water fluxes, and to interpret the processes that may be linked to DOC changes, and 4) to estimate the DOC annual circulation in the plantation water fluxes.

\section{METHODS}

Study site. The study was done in three plots of Eucalyptus grandis plantations of South-African seed provenance located at the Concordia Experimental Station of the National Agricultural Technology Institute ( $31^{\circ} 22^{\prime} \mathrm{S}, 58^{\circ} 07^{\prime} \mathrm{W}$, $47.5 \mathrm{~m}$ a.s.1.), Province of Entre Ríos, Argentina. Annual precipitation in the period $1992-2006$ was $1,388 \mathrm{~mm}$ and mean temperature attained $18.9^{\circ} \mathrm{C}$. Soil type at plantation was dark brown loamy sand (Haplumbrept, Inceptisol). Trees were planted at 3 x 3 m in October 16th, 1992.

Field sampling. Water samples for DOC analyses and color measurements were obtained for each one of the 37 precipitation events from May 2004 to March 2006. We discarded a few throughfall and precipitation samples contaminated by bird faeces, insects and/or leaves in the samplers, observed during collection. With the exception of the water table (sampled in one pipe hole) the sampling was done by triplicate in plantations and their vicinity: three open sites for precipitation, three plots for throughfall and stemflow, three quadrats for surface flow, three lysimetric trays for litter lixiviation, and three lysimeters for subsurface flow. Water samples were collected from devices specifically devoted to DOC analyses, two hours after diurnal precipitation events and at 9 am following nocturnal precipitation events. Precipitation was sampled in plastic rain gauges 20 $\mathrm{cm}$ in diameter. The precipitation samples contained the organic carbon deposited in the dry and rainy periods preceding sampling dates; occasionally, samples corresponded to isolated rainy events. Throughfall and stemflow were measured in 3-100 $\mathrm{m}^{2}$ plots. In each plot we employed one $2 \mathrm{~m}$ long throughfall-DOC sampling device supporting a battery of 4 independent plastic water collecting sets $-20 \mathrm{~cm}$ diameter funnel, connecting tubing and bottle- provided with $1 \mathrm{~mm}^{2}$ mesh to prevent contamination, located $1 \mathrm{~m}$ aboveground. If a collecting set was contaminated, the subsample was discarded. Water collected was integrated in a composite throughfall water sample per plot. All sets were replaced by clean ones after each rain event. At each plot, the stemflow sample was obtained from the total water collected from the eleven trees per plot; in each individual tree we installed an aluminum collar bonded with silicon rubber around the trunk at $1.30 \mathrm{~m}$ over the surface, connected to a plastic container on the ground with flexible plastic tubing with vapor trap. Litter lixiviation water samples were obtained from one $81 \times 50 \mathrm{~cm}$ lysimetric zero-tension tray per 
plot, located below litter at the top of the A1 soil horizon, and connected to a container located in a soil pit. Surface runoff was obtained in three $3 \times 3 \mathrm{~m}$ plots with a tree inside, defined in three laterals by a plastic pipe, $10 \mathrm{~cm}$ in diameter, opened 30 degrees in the side towards the plot, and a $15 \mathrm{~cm}$ wide plastic sheet running along the pipe inside it and inserted $5 \mathrm{~cm}$ in a cut in the soil parallel to the surface at $2 \mathrm{~cm}$ of depth to avoid water loss in the interface soil-pipe; the pipe was connected in its lowest corner to a plastic container located in a soil pit. The upper side of the surface flow parcel consisted in a $20 \mathrm{~cm}$ wide $\mathrm{x} 20 \mathrm{~cm}$ deep trench to derive the surface flow from upper ground outside the plot. Water table was sampled at a depth $(\mathrm{n}=21)$ of $10.36 \pm 0.24 \mathrm{~m}$ in a pipe hole located inside one of the plantation plots. Samples of approximately $500 \mathrm{~cm}^{3}$ were cooled, conditioned in isolating foam containers and sent by bus overnight to the LISEA Lab the same day they were taken.

Laboratory analyses. The samples obtained on field were processed during the following 48 hours. They were filtered using a polycarbonate filter holder, $0.45 \mu \mathrm{m}$ filter membranes, both Millipore brand, and a vacuum pump. Color (optical density) was measured with a spectrophotometer Metrolab 325, at $365 \mathrm{~nm}$ employing $1 \mathrm{~cm}$ path-length glass cuvettes. Aliquots of $125 \mathrm{~cm}^{3}$ of filtered samples were sent by international courier to the IITF-USDA Forest Service, Río Piedras, Puerto Rico, for DOC analyses with a Lachat Instruments Model IL550 TOC-TN Analysis System.

Dissolved organic carbon annual circulation. We employed the available data from a 2-year water balance study of Tesón (2012) for the same plantations and the DOC concentrations of the present study to model the DOC annual circulation. For the periods April - March 2003-2004 and 2004-2005, we added the products of each water flux measurements per its DOC concentration. For the few sampling intervals without DOC measurements, we employed the significant regressions between DOC concentration and water flux obtained in the present study, or the DOC weighted means for fluxes when regressions were not significant.

Fine litter fall. Fine litter fall was measured employing three $0.5 \mathrm{~m}^{2}$ square litter traps located at random at 0.5 $\mathrm{m}$ aboveground in each one of the three pseudo-replicated plantation plots. Fallen fine litter was collected every two weeks during 24 months, from April 2004 to March 2006, separated into leaves, fine branches, bark and fruits. Fractions were dried in oven at $70{ }^{\circ} \mathrm{C}$ to constant weight and the dry weight of the annual total fine litter fall converted into carbon employing a carbon to dry weight relationship of $424 \mathrm{mg}$ of carbon per $1 \mathrm{~g}$ of dry weight, reported for the same plantation by Goya et al. (2009).

Statistics. A simple, ordinary least squares regression analysis was carried out to model the dependence of DOC on flux intensity. Adjusted $\mathrm{R}^{2}$ and visual inspection of residuals were used as criteria in model selection. A simple linear regression of DOC on color in flux samples was calculated separately for each flux. Slopes and intercepts were compared using a multiple linear regression (Kleinbaum and Kupper 1978) including $\mathrm{k}-1$ dummy variables $(\mathrm{k}=$ number of fluxes) for intercepts comparison and dummy $\mathrm{x}$ color interactions for slopes comparison. A quantile regression was used in order to calculate a common model for all fluxes. This technique is appropriate in case of lack of variance homogeneity along the regression line for the calculation of confidence limits (Cade and Noon 2003). Quantile regression lines were calculated for $5 \%$ and $95 \%$ quantiles and taken as lower and upper $90 \%$ confidence limits for the regression line.

\section{RESULTS}

Water budget. Table 1 reports the water budget data on the same plantation extracted from Tesón (2012). Bulk precipitation attained 1,471 mm (year 2003-2004) and 1,265 mm (year 2004-2005). Throughfall was circa $84 \%$ and stemflow was 4 to $5 \%$ of bulk precipitation. Litter interception attained up to $16 \%$ of bulk precipitation. Eucalyptsgrandis transpiration was 69 to $75 \%$ of bulk precipitation, and total evapotranspiration represented 96 to $99 \%$ of bulk precipitation. Percolation during these years was among 1 to $4 \%$ of bulk precipitation.

Dissolved organic carbon concentration and $\mathrm{pH}$. The DOC concentration in precipitation, throughfall and stemflow (figures 1A, 1B and 1C, respectively) was curvilinear. The different water fluxes showed different DOC concentration range (table 2). With the exception of stemflow, presenting

Table 1. Annual water budgets, for the interval April to March of years 2003 to 2004 and 2004 to 2005 of the studied Eucalyptus grandis plantation. Water fluxes are reported in millimeters per year (source: Tesón 2012).

Balances hídricos anuales, para los intervalos entre los meses abril y marzo de 2003 a 2004 y 2004 a 2005, de la plantación de Eucalyptus grandis estudiada. Los flujos son indicados en milímetros por año (fuente: Tesón 2012).

\begin{tabular}{lrr}
\hline \multirow{1}{*}{ Fluxes / year } & \multicolumn{2}{c}{ Water $(\mathrm{mm})$} \\
\cline { 2 - 3 } & $2003-2004$ & $2004-2005$ \\
\hline Bulk precipitation & 1,417 & 1,265 \\
Stemflow & 73 & 48 \\
Throughfall & 1,192 & 1,065 \\
Net precipitation & 1,265 & 1,113 \\
Canopy interception & 152 & 153 \\
Transpiration & 981 & 944 \\
Litter interception & 232 & 152 \\
Evapotranspiration & 1,365 & 1,249 \\
Percolation & 52 & 16 \\
\hline
\end{tabular}



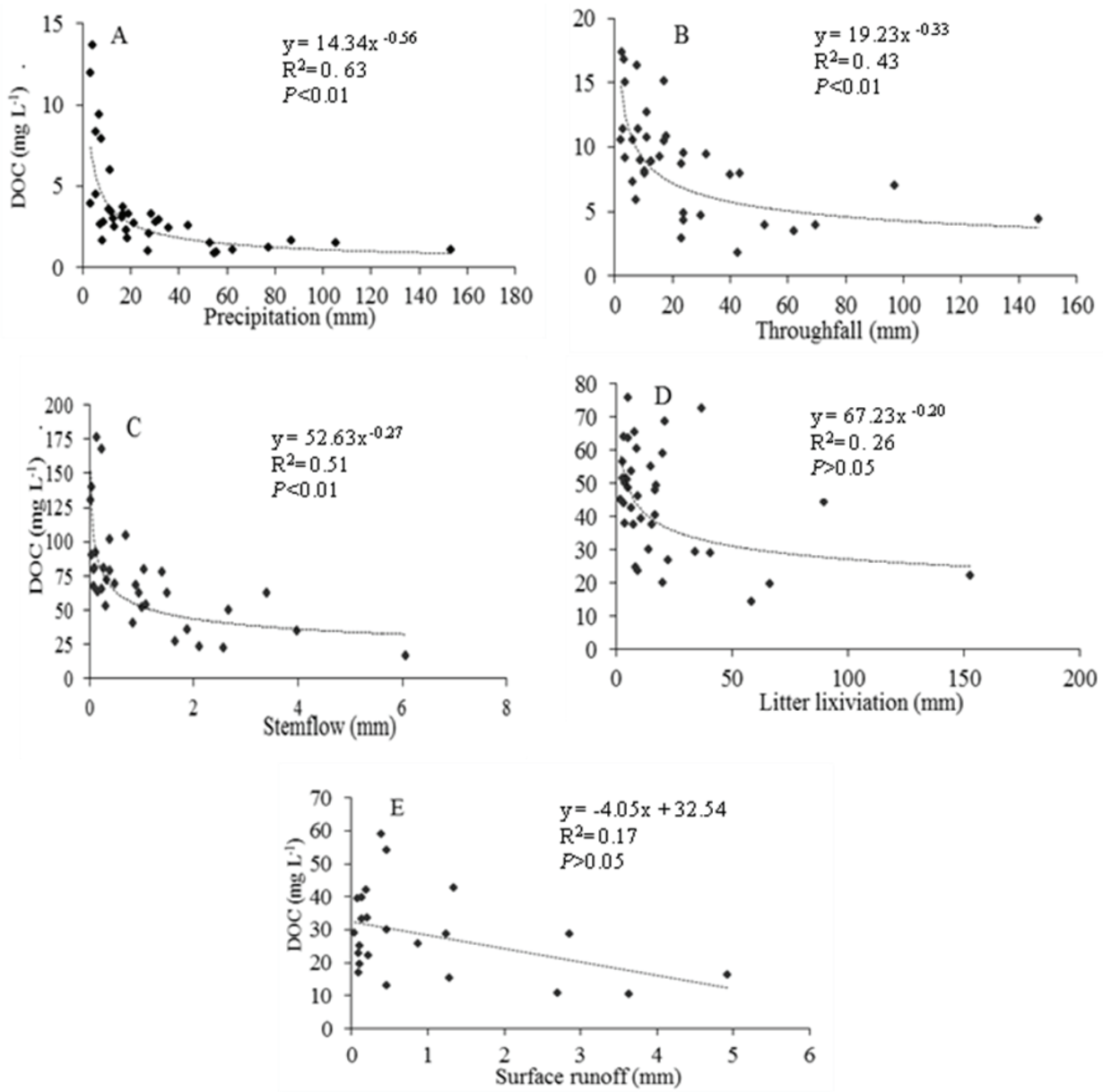

Figure 1. Relationship between dissolved organic carbon(DOC) concentration and flux intensity. Results of a multiplicative regression model fit are presented for each flux: precipitation (A), throughfall (B), stemflow (C), litter lixiviation (D) and surface runoff (E).

Relación entre la concentración de COD y la intensidad del flujo de agua. Los resultados de un ajuste a un modelo multiplicativo de regresión es presentado para cada flujo: precipitación (A), trascolación (B), flujo caulinar (C), lixiviación del mantillo (D) y escurrimiento superficial (E).

the highest DOC concentration, there was an increase along the vertical flux sequence from precipitation towards the soil organic horizons. Far belowground, more than $10 \mathrm{~m}$ in depth, the water table DOC concentration was low with the lowest range, and the mean did not significantly differed from DOC concentration in precipitation (table 2). The DOC concentration in precipitation, throughfall and stemflow was inversely related to water flux intensity and with a relatively high correlation degree, while the behavior in litter lixiviation and surface runoff (figures $1 \mathrm{D}$ and $1 \mathrm{E}$, respectively) was highly different and less significant.

The $\mathrm{pH}$ of water fluxes did not changed significantly among gross precipitation and throughfall (ca. 6.4) or among precipitation and the water table, though it was slightly acidic in stemflow (5.5 \pm 0.1$)$ and near neutrality (6.6 to 6.8$)$ in water lixiviating litter and surface runoff.

Dissolved organic carbon vs color. Statistical analyses of DOC concentration vs color for individual fluxes showed differences in the y-axis intercept and the slope values of regression lines (table 2, figures $2 \mathrm{~A}$ and $2 \mathrm{~B}$ ). The value of intercept for all fluxes (total) equation did not significantly differ from zero (table 2, figure 3 ). However, individual flux analyses showed different types of y-axis intercept. Precipitation and throughfall presented low values of y-axis intercept, with neither a significant difference in intercept nor in the slope of regression line between them (table 2). In stemflow, litter lixiviation and surface runoff presented higher $y$-axis intercepts, though these values were not significantly different. Notwithstanding, the slopes of regression lines for these three fluxes were significantly different; showing the highest value for stemflow and the lowest for surface runoff (table 2).

Dissolved organic carbon annual circulation in E. grandis plantation. The atmosphere supplied $c a .25-30 \mathrm{~kg} \mathrm{ha}^{-1}$ year ${ }^{-1}$ of DOC, canopy and trunks leaching 76 to $98 \mathrm{~kg} \mathrm{ha}^{-1}$ year ${ }^{-1}$ of DOC and litter 272 to $276 \mathrm{~kg} \mathrm{ha}^{-1}$ year $^{-1}$ of DOC. Aboveground DOC input to mineral horizons was 348.0 to $374.4 \mathrm{~kg} \mathrm{ha}^{-1}$ year $^{-1}$ (figure 4). 
Table 2. Dissolved organic carbon (DOC) vs color regression parameters per flux and parameter comparison.

Parámetros de regresión de COD vs color por flujo y comparación de parámetros.

\begin{tabular}{|c|c|c|c|c|c|c|c|c|}
\hline Flux & $\mathrm{n}$ & Intercept & Slope & $\mathrm{R}^{2}$ & $\begin{array}{l}\text { DOC mean } \\
\left(\mathrm{mg} \mathrm{L}^{-1}\right)\end{array}$ & $\begin{array}{l}\text { DOC range } \\
\left(\mathrm{mg} \mathrm{L}^{-1}\right)\end{array}$ & $\begin{array}{c}\text { Color range } \\
\text { (optical density)* }\end{array}$ & $\mathrm{pH}$ \\
\hline All & 395 & $0.84+$ & 103.28 & 0.93 & - & $0.71-242.60$ & $0.003-1.921$ & - \\
\hline Precipitation & 69 & $2.09 \mathrm{a}$ & 71.38 a & 0.60 & $2.02 \pm 0.36$ & $0.71-13.67$ & $0.003-0.123$ & $6.4 \pm 0.2$ \\
\hline Throughfall & 109 & $1.35 \mathrm{a}$ & 75.82 a & 0.80 & $6.47 \pm 0.78$ & $1.67-23.24$ & $0.003-0.237$ & $6.4 \pm 0.0$ \\
\hline Stemflow & 100 & $15.67 \mathrm{~b}$ & $103.19 \mathrm{~b}$ & 0.83 & $67.52 \pm 11.10$ & $4.69-242.60$ & $0.046-1.921$ & $5.5 \pm 0.1$ \\
\hline Litter lixiviation & 73 & $10.99 \mathrm{~b}$ & 68.39 a & 0.67 & $36.24 \pm 4.09$ & $2.55-39.59$ & $0.152-1.103$ & $6.6 \pm 0.0$ \\
\hline Surface runoff & 44 & $12.09 \mathrm{~b}$ & 46.47 c & 0.62 & $36.25 \pm 26.02$ & $9.01-63.68$ & $0.109-1.097$ & $6.8 \pm 0.2$ \\
\hline Water table & 6 & - & - & - & $1.57 \pm 0.56$ & $1.15-2.24$ & - & $6.1 \pm 0.2$ \\
\hline
\end{tabular}

* $\log$ of transmittance (\%), $1 \mathrm{~cm}$ path-length cuvette. All parameters and $\mathrm{R}^{2}$ were significantly different from 0 at $\alpha=0.01$ except those with + . Different letters indicate significant differences among parameters $(P<0.05)$.
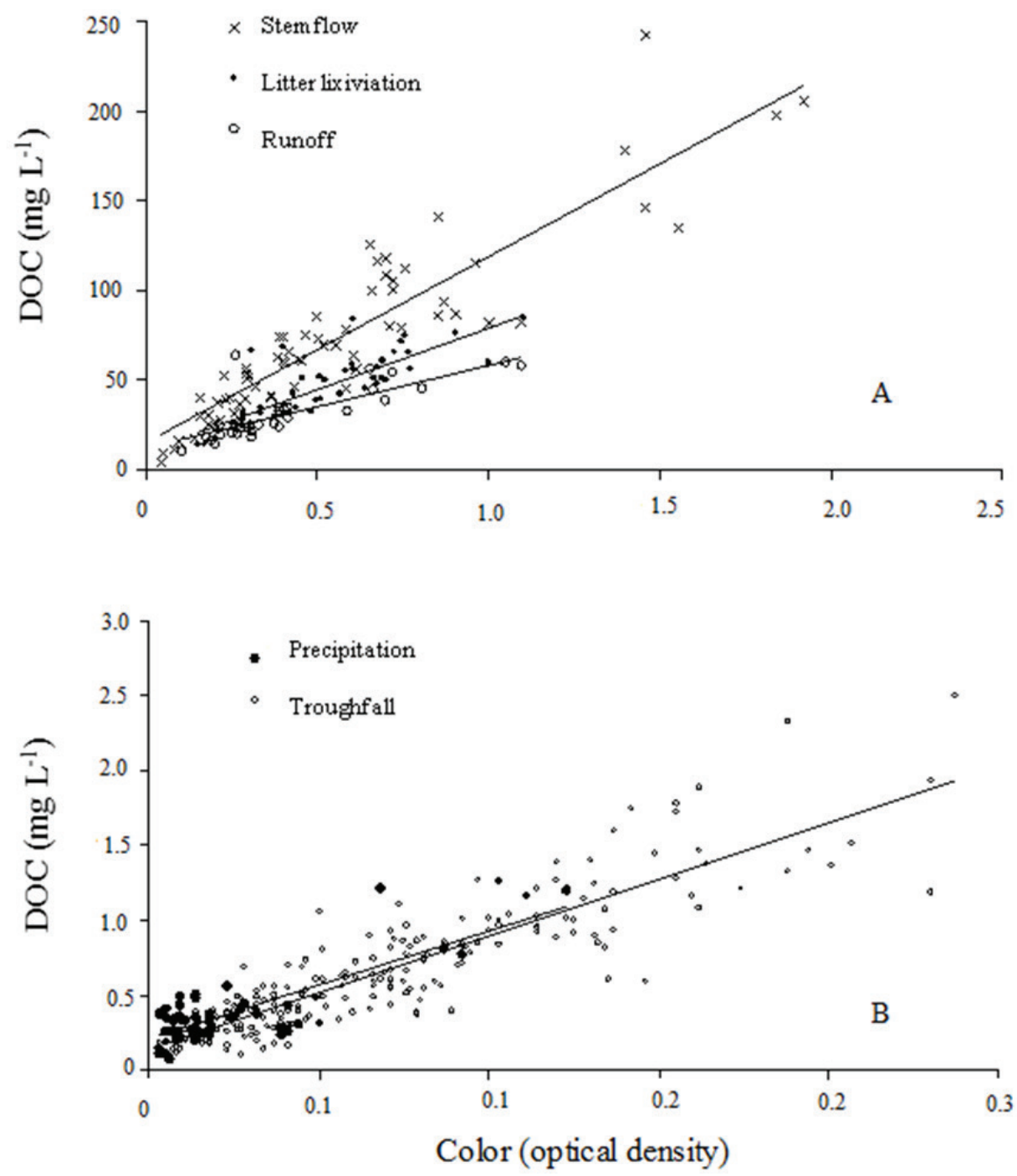

Figure 2. Relationship between DOC concentration and color per flux: stemflow, litter lixiviation and surface runoff (A); precipitation and throughfall (B). Ordinary least square regression lines are indicated.

Relación entre la concentración de COD y el color por flujo hídrico: flujo caulinar, lixiviación del mantillo y escurrimiento superficial (A); precipitación y trascolación (B). Se indican las líneas de regresión por cuadrados mínimos ordinarios. 


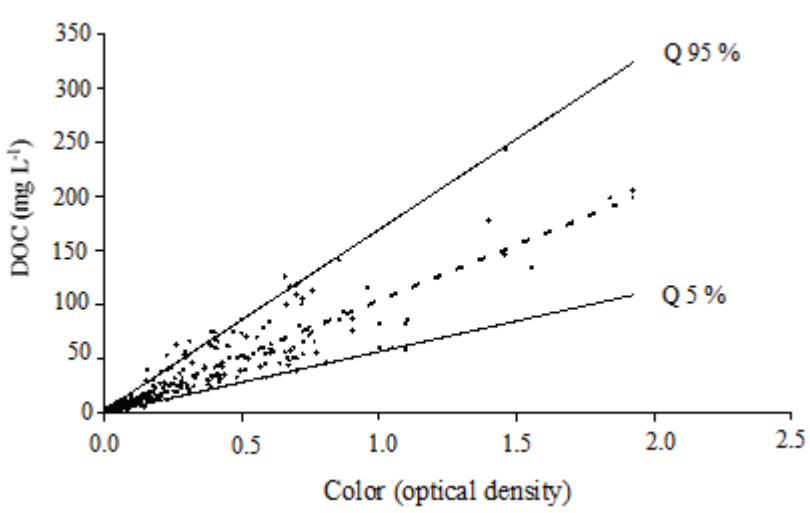

Figure 3. Relationship between dissolved organic carbon (DOC) concentration and color for all fluxes. Ordinary least squares (dotted line) and confidence limits based on quantile regression are indicated. Q $5 \%$ : intercept $=0.25$, slope $=56.56$; Q $95 \%$ : intercept $=0.53$, slope $=167.01$.

Relación entre la concentración de COD y el color para todos los flujos hídricos. Se indica la línea por mínimos cuadrados ordinarios (línea de puntos) y límites de confianza basado en la regresión de cuantiles. Q $5 \%$ : intercepción $=0,25$, pendiente $=56,56$; Q $95 \%$ : intercepción $=0,53$, pendiente $=167,01$.
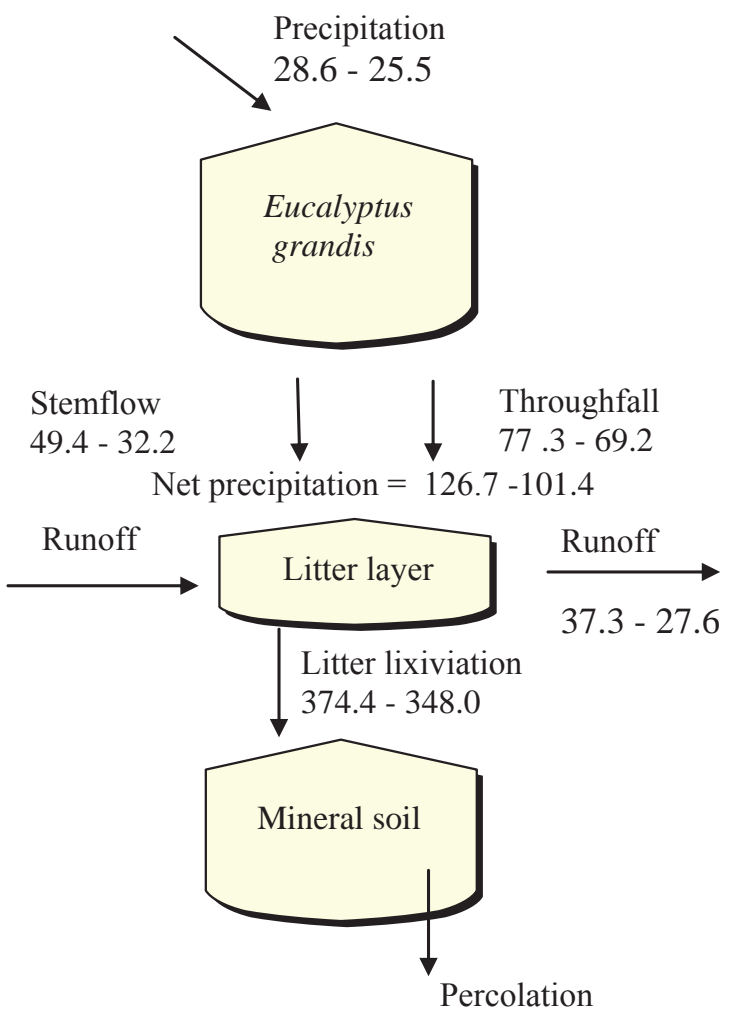

Figure 4. Annual dissolved organic carbon (DOC) circulation model in Eucalyptus grandis plantation. Both numbers in each flux are for the periods April- May 2003 - 2004, and 2004 - 2005, respectively. Fluxes are in $\mathrm{kg} \mathrm{ha}^{-1}$ year $^{-1}$ DOC.

Modelo de circulación anual de COD en la plantación de Eucalyptus grandis. Los dos números de cada flujo corresponden a los periodos abril-mayo de 2003 a 2004, y de 2004 a 2005, respectivamente. Los flujos se indican en $\mathrm{kg} \mathrm{ha}^{-1}$ año ${ }^{-1}$ de COD.

\section{DISCUSSION}

Water budget. Bulk precipitation in both studied years, respectively, was $2 \%$ more and $9 \%$ less than mean annual precipitation $(1,388 \mathrm{~mm})$ for the previous 14 years; hence, obtained water fluxes values appear to represent a good approach to the mean water budget. Throughfall was the main component of net precipitation and stemflow the lowest; however, stemflow significantly contributes with water and nutrients to the immediate surroundings of the trunks. Litter interception, a pathway less commonly reported in literature, was higher than canopy interception. As a result of canopy and litter interception, water arriving to the mineral soil surface potentially available to infiltrate and to contribute to surface runoff was reduced to 73 to $76 \%$ of bulk precipitation. Transpiration was the main component of gaseous losses from the plantation, being more than $2 / 3$ of total evapotranspiration. Under the present "normal" mean rain conditions, total gaseous water losses by physical evaporation and biological transpiration attained 96 to $99 \%$ of bulk precipitation highlighting the high water consumption and gaseous losses of these plantations leaving scarce water that may percolate and contribute to the water table.

Dissolved organic carbon concentration and $p H$. There are two different approaches considered in the discussion below. The first is a general overview of DOC concentration change in the framework of water circulation pathways through the plantation ecosystem, and the second is a particular analysis of DOC concentration change according to the intensity of bulk precipitation events and, consequently, of derived water flows.

A similar trend of total DOC increment in the sequence from precipitation to throughfall and stemflow observed in the E. grandis plantation was reported for some forests too (Moreno et al. 2001, Xu et al. 2005). However, the magnitude among fluxes differed significantly, since in the E. grandis plantation DOC concentrations in throughfall and stemflow were 3.2 and 33.4 times respectively higher as those in the precipitation, meanwhile, for example, $\mathrm{Xu}$ et al. (2005) reported 2.7 and 3.6 times, respectively.

The increase of DOC in net precipitation fluxes could happen due to evaporation water losses at the canopy, but also because of organic carbon incorporation from surfaces in contact with flowing water. The stemflow in this E. grandis plantation, as mentioned represents a little percentage of bulk precipitation, shows an increase in DOC concentration in magnitude compared to throughfall, as a consequence of the contact of small water quantities with the surface of leaves, branches and trunk. Extremely high DOC concentrations in stemflow were obtained during low intensity and short duration precipitation events (figure 1C). A wide range in stemflow and throughfall DOC concentration was also observed in Quercus pyrenaica Willd, Betula papyrifera Marshand Larix laricina (Du Roi) K. Koch (Mahendrappa 1974, Moreno et al. 2001). 
Although DOC concentration in litter lixiviation and surface runoff was high, it was lower than in stemflow, probably because the main contribution of water to the ground was provided by throughfall diluting the stemflow DOC contribution. Also, high concentrations of DOC in litter lixiviation and in surface runoff include the labile organic compounds dissolved from decomposing material including fine detritus (recently fallen and old leaves, twigs and small branches, bark, miscellanea and microorganisms) and colored humic compounds. DOC concentration decreased in waters flowing below the fine root mat, suggesting that topsoil complex efficiently retained and used organic carbon. The filtering process in soil and subsoil resulted in a low DOC concentration at the water table (table 2); notwithstanding it might be the collective effect of natural, agricultural and forestry ecosystems mosaic in the watershed.

The similarity of $\mathrm{pH}$ among gross precipitation and throughfall suggests that processes at canopy do not affect water acidity; meanwhile, processes at trunk surfaces linked to formation of organic acids, as explained below, produce a more acidic stemflow. Other studies reported that mean $\mathrm{pH}$ of throughfall and stemflow was slightly more acidic compared to precipitation (Oyarzún et al. 1998, Lin et al. 2000, Liu et al. 2003, Xu et al. 2005) and has been attributed to the corresponding increase in organic acids (Oyarzún et al. 1998). Possibly different canopy structure, foliar behavior and chemistry of species contribute to explain the differences mentioned.

Also, in relation to pH, Jobbágy and Jackson (2003) mentioned that soil acidification following afforestation can potentially be explained by three complementary mechanisms: 1) organic acids inputs, 2) increasing soil respiration, and 3) cation sequestration and redistribution. The $\mathrm{pH}$ vertical patterns observed in Eucalyptus grandis plantations suggest that organic acid inputs are unlikely to be the cause of the acidification observed; they would have entered the soil predominantly from the surface, causing maximum acidification in the top soil. Soil acidification in Eucalyptus spp. plantations has been attributed to cation sequestration and redistribution (Jobbágy and Jackson 2003, Jobbágy et al. 2006).

The second mentioned approach, focused in DOC concentration change with water flux intensity, deserved additional considerations. The higher dispersion values of DOC in canopy water fluxes, during low intensity events, are probably expressing differences in the previous dry period duration and atmospheric conditions affecting accumulation and availability of organic carbon in the atmosphere and plant surfaces that may be washed. Above some thresholds in water fluxes intensity $(>30 \mathrm{~mm}$ in bulk precipitation, $>40 \mathrm{~mm}$ in throughfall, and $>1.5 \mathrm{~mm}$ in stemflow) DOC concentration tends to stabilize in low values. Although litter lixiviation and surface runoff showed different patternsconcerning the other compartments, in general, they exhibit a tendency of DOC values dispersion and lower concentrations with the increment of water fluxes which is in connection to the availability of DOC to be washed (figure 1).
Dissolved organic carbon vs color. The non significant difference from zero of the y-axis intercept value for the equation of all fluxes analyzed together suggests the absence of colorless organic compounds. In this regression the lowest DOC concentrations and color intensity values were provided by precipitation and throughfall data.

In the DOC concentration vs color considered separately for each flux, the low values of y-axis intercept of regression lines for precipitation and throughfall would be indicating scarcity or absence of colorless organic carbon that, together with a non-significant difference in the slope of regression line between them, indicate a similar DOC composition and low concentration with compounds of low molecular weight in both fluxes. Relatively high photosynthetic active radiation ( $20 \%$ of outside PAR) below tree canopy, low leaf area index (1.7) and high frequency of gaps in foliage (Tesón 2012) allowed some direct precipitation input as throughfall that could explain DOC similarities among these fluxes.

Contrary sense, the highest $y$-axis intercept value of DOC concentration vs color in stemflow suggested a high concentration of colorless low molecular weight and less polymerized metabolites easily decomposable, significantly different from that of precipitation-throughfall. The high y-axis intercepts in fluxes associated with litter (litter lixiviation and surface runoff) indicated concentrations of colorless DOC in the same order of stemflow. The high concentration of colorless DOC encountered in stemflow may be generated by microbial mediated processes through co-metabolism that contributes to the decay of refractory compounds such as lignin and their derivatives (Horvath 1972, De Haan 1974, De Haan 1977, Geller 1985, Kim and Hao 1999, Dubasquier et al. 2002, Netzer et al. 2004, García-Rivero and Peralta-Pérez 2008). On the other hand, in litter lixiviation and surface runoff, colorless organic substances are supposed to be associated with lixiviation and decomposition of fine litter, supplied by net precipitation and concentrated by evaporation from the ground.

Slope differences were indicative of changes in DOC concentrations per unit of color and showed that equal DOC concentrations had different visible light absorption capacity depending on water flux; suggesting that colored organic compounds differed in structure and/or molecular weight in different water flux sets. Beyond the values of slopes obtained, it is important to note the difference between precipitation and throughfall, on the one hand, with stemflow, and in the other hand with litter lixiviation and surface runoff. In bulk precipitation and throughfall the DOC concentration and color intensity were low, but the last is not a real color and the absorption detected in the spectrophotometric measurements was possibly due to the scatter light produced by colloidal forms surviving the filtration process. On the contrary in stemflow, litter lixiviation and surface runoff fluxes, there was a high concentration of DOC, with a real color, mainly yellow-tobrown color that absorbs visible light to a higher extent. 
In the case of these fluxes, the values of regression line slopes suggest the intervening mechanism. At the beginning, heterotrophic microbial activity supplies stemflow with mainly lignin-derived colored dissolved substances favored by co-metabolism processes and, later, a recombination that produces organic compounds. This mechanism may explain the supply of dissolved organic compounds of aromatic characteristics that absorb visible light similarly to what is observed in humic substances in aquatic ecosystems. In litter lixiviation and surface runoff the humification process occurring in soils gives origin to DOC of high molecular weight. Although these organic compounds are chemically analogous to what was found in stemflow, the obtained values of regression line slopes indicate a decreasing DOC concentration per color unit in the sequence stemflow- litter lixiviation- surface runoff. This may be related to the increment of molecular weight of DOC as a consequence of the soil humification process. The large molecules originated not only absorb light, due to electronic transitions, but also can scatter light to a higher extent than lower ones (Chen et al. 1977, Bloom and Leenheer 1989) and promote a reduction of transmitted radiation inside the spectrophotometric cell which results in higher absorption. Then, the slope DOC per color unit becomes lower as size of the molecules involved increases. Therefore, decreasing values of slopes from stemflow to litter lixiviation and finally to surface runoff indicate the increment of the polymerization degree of DOC compounds among these fluxes.

Summarizing, our results support a lower DOC supply to throughfall due to canopy lixiviation and washing; meanwhile, abiotic and biotic sources on plant surface supply DOC to stemflow. Lignin decomposition is the origin of polyphenols, sugars and quinones that begin condensation reactions with synthesis of colored compounds of high molecular weight. At soil, condensation reactions produce humic colored substances of higher molecular weight. In general, the structure of the mentioned compounds contains groups of carboxylic acid, quinones, ketones, phenols and alcoholic hydroxyls into a skeleton of aromatic rings cross-linked principally by oxygen and nitrogen bridging groups (Stevenson 1982).

Dissolved organic carbon annual circulation in E. grandis plantation. Annual circulation of DOC involved only a few hundreds of kilograms per hectare per year (figure 4). As throughfall contributes with more water (84-85\% of gross precipitation) with lower DOC concentration (6.5 $\left.\mathrm{mg} \mathrm{L}^{-1}\right)$ to net precipitation than does stemflow (4-5\% of gross precipitation and $67.5 \mathrm{mg} \mathrm{L}^{-1}$ ), the relative DOC returnin net precipitation (61-68 \% by throughfall and 21$29 \%$ by stemflow) supplied by the mentioned flows is more balanced. As the spatial distribution of both flows and the organic carbon quality and concentration differ, the effect on the biota and soil may be different. This has been reported by Laclau et al. (2010) who found that lar- ge amounts of water with high concentrations of nutrients from the stemflow infiltrated at the base of the trunks contributed to increase the spatial variability of fine root densities and of soil chemistry in the upper layers.

The $74-78 \%$ of aboveground DOC input to mineral horizons was provided by litterfall mediated by processes in litter. As fine litterfall was $2 \mathrm{Mg} \mathrm{ha}^{-1}$ year ${ }^{-1}$ of carbon, DOC originated in litter and mainly incorporated annually to the soil was about $14 \%$ of litterfall. As DOC outputs in surface runoff could be compensated by inputs from the surrounding spontaneous ecosystems, DOC losses in runoff may attain a maximum of 8 to $10 \%$ of DOC entering the mineral soil.

\section{CONCLUSIONS}

It is concluded that in a plantation of Eucalyptus grandis at rotation end in Entre Ríos, Argentina, the DOC in water fluxes show molecular properties, concentration mean and range, and changes among fluxes in ways similar to those observed in native forests. Differences may be explained by factors influencing water gains and losses but also by factors and processes affecting composition and availability of organic matter that may solubilize in waters in contact with biomass, necromass, soil and subsoil. However, organic acids and $\mathrm{pH}$ in waters infiltrating mineral horizons do not suggest a possible contribution to soil acidification.

The relationships between DOC and optical density evidenced by regression analyses permit the use of regression parameters as useful tools to characterize the chemical composition of DOC and also to interpret DOC changes in waters circulating inside the planted ecosystem. The regression equations obtained between DOC concentration and optical density measured with visible light spectrophotometers may be employed to estimate DOC in the different water fluxes by means of general and specific equations.

The annual circulation model of DOC led us to conclude that the atmospheric contribution of dissolved organic carbon to the plantation is low, that the aboveground biomass leaching contribution is around three times larger, and that DOC input to mineral soil is mainly from litterfall inputs to the forest floor.

\section{ACKNOWLEDGEMENTS}

This study was done under the cooperation agreement between Universidad Nacional de La Plata, Argentina, and the International Institute of Tropical Forestry (IITF, USDA Forest Service), Puerto Rico. We appreciate the collaboration of Mariana Dabadie (LISEA-UNLP- CICPBA), Mary Jeanne Sánchez and crew from IITF, and the authorities of EEA INTA Concordia. This work was funded by the Agencia Nacional de Promoción Científica, Argentina (PICT 1000/61), Academia Nacional de Agronomía y Veterinaria of Argentina and Consejo Nacional de Investigaciones Científicas y Técnicas (CONICET). 


\section{REFERENCES}

Bloom PR, JA Leenheer. 1989. Vibrational, electronic, and highenergy spectroscopic. Methods for characterizing humic substances. In Hayes MHB, P MacCarthy, RL Malcolm, RS Swift eds. Humic substances II. In search of structure. New York, United States. John Wiley. p. 409-446.

Cade BS, BR Noon. 2003. A gentle introduction to quantile regression for ecologists. Frontiers in Ecology and the Environment 1: 412-420.

Chapin FS III, PA Matson, HA Mooney. 2002. Principles of terrestrial ecosystems. Springer. $436 \mathrm{p}$.

Chen Y, N Senesi, M Schnitzer. 1977. Information provided on humic substances by E4/E6 ratios. Soil Science Society American Journal 41: 352-358.

Conzonno VH, A Fernández Cirelli. 1988. Soluble humic substances from Chascomús Pond (Argentina). Factors influencing distribution and dynamics. Archiv für. Hydrobiologie 111: 467473.

Conzonno VH, A Fernández Cirelli. 1995. Dissolved organic matter in Chascomús Pond (Argentina). Influence of calcium carbonate on humic acid concentration. Hydrobiologia 297: 55-59.

Conzonno VH, A Fernández Cirelli. 1996. Humic substances and phytoplankton primary production in Chascomús Pond (Argentina). Facts and speculations. Revista de la Asociación de Ciencias Naturales del Litoral 27(1): 35-42.

De Haan H. 1972. Molecule size distribution of soluble humic compounds from different natural waters. Freshwater Biology 2: 235-241.

De Haan H. 1974. Effect of a fulvic acid fraction on the growth of a Pseudomonas from Tjeukemeer (The Netherlands). Freshwater Biology 4: 301-310.

De Haan H. 1977. Effect of benzoate on microbial decomposition of fulvic acids in Tjeukemeer (The Netherlands). Limnology and Oceanography 22: 38-44.

De Haan H, T De Boer, HA Kramer, J Voerman. 1982. Applicability of light absorbance as a measure of organic carbon in humic lake water. Water Research 16: 1047-1050.

Dubasquier D, S Revah, R Auria. 2002. Biofiltration of Methyl tert-Butyl Ether Vapors by Cometabolism with Pentane: Modeling and Experimental Approach. Environmental Science Technology 36: 247-253.

Frangi JL, MD Barrera, J Puigdefábregas, P Yapura. AM Arambarri, LL. Richter. 2004. Ecología de los Bosques de la Tierra del Fuego. Chap 18, 88 pages. In Arturi MF, JL Frangi, JF Goya eds. Ecología y Manejo de los Bosques de Argentina. EDULP (Editorial Universidad Nacional de La Plata). ISBN 950-34-0307-3.

García-Rivero M, MR Peralta-Pérez. 2008. Cometabolismo en la biodegradación de hidrocarburos. Revista Mexicana de Ingeniería Química 7: 1-12.

Geller A. 1985. Degradation and formation of refractory DOM by bacteria during simultaneous growth on labile substrates and persistent lake water constituents. Schweizerische Zeitschrift für Hydrologie 47: 27-44.

Ghosh K, M Schnitzer. 1979. UV and visible absorption spectroscopic investigations in relation to macromolecular characteristics of humic substances. Journal of Soil Science 30: 735-745.

Goya JF, JL Frangi, G Denegri, F Larocca. 2009. Simulación del impacto de diferentes regímenes de cosecha sobre el capital de nutrientes e indicadores económicos en plantaciones de Eucalyptus grandis del NE de Entre Ríos, Argentina. AUGMDOMUS 1: 1-17.

Harmon ME, JF Franklin, FJ Swanson, P Sollins, SV Gregory, et al. 1986. Ecology of coarse woody debris in temperate ecosystems. Advances in Ecological Research. 15: 133302.

Horvath RS. 1972. Microbial co-metabolism and the degradation of organic compounds in nature. Bacteriological Review 36: 146-155.

Jobbágy EG, RB Jackson. 2003. Patterns and mechanisms of soil acidification in the conversion of grassland to forests. Biogeochemistry 64: 205-229.

Jobbágy EG, M Vasallo, KA Farley, G Piñeiro, M Garbulsky, MD Nosetto, RB Jackson, JM Paruelo. 2006. Forestación en pastizales: hacia una visión integral de sus oportunidades y costos ecológicos. Agrociencia 10: 109-124.

Kim M, O Hao. 1999. Cometabolic degradation of chlorophenols by Acinetobacter species. Water Research 33: 562-574.

Kimmins JP. 1997. Forest ecology. New Jersey, USA. Prentice Hall. 595 p.

Kleinbaum DG, LL Kupper. 1978. Applied regression analysis and other multivariable methods. Boston, United States. Duxbury Press. 322 p.

Laclau JP, J Ranger, JP Bouillet, JD Nzila, P Deleporte. 2003. Nutrient cycling in a clonal stand of Eucalyptus and an adjacent savanna ecosystem in Congo. 1. Chemical composition of rainfall, troughfall and stemflow solutions. Forest Ecology and Management 176: 105-119.

Laclau JP, J Ranger, JL Moraes Gonçalves, V Maquere, AV Krusche, AT M'bou, Y Nouvellon, L Saint-Andre, JP Bouillet, M Cassia Piccolo, P Deleporte. 2010. Biogeochemical cycles of nutrients in tropical Eucalyptus plantations. Main features shown by intensive monitoring in Congo and Brazil. Forest Ecology and Management 259: 1771-1785.

Lambers H, FS Chapin III, TL Pons. 1998. Plant physiological ecology. Springer. $540 \mathrm{p}$.

Lin TC, SP Hamburg, HB King, YJ Hsia. 2000. Throughfall patterns in a subtropical rain forest of northeastern Taiwan. Journal of Environmental Quality 29: 1186-1193.

Liu W, JED Fox, ZF Xu. 2003. Nutrient budget of a montane evergreen broad-leaved forest at Ailao Mountain National Nature Reserve, Yunnan, southwest China. Hydrological Processes 17: 1119-1134.

Mahendrappa M. 1974. Chemical composition of stemflow from some eastern Canadian tree species. Canadian Journal of Forest Research 4: 1-7.

Moreno G, JF Gallardo, F Bussotti. 2001. Canopy modification of atmospheric deposition in oligotrophic Quercus pyrenai$c a$ forests of an unpolluted region (central-western Spain). Forest Ecology and Management 149: 47-60.

Netzer R, P Peters-Wendisch, L Eggeling, H Sham. 2004. Cometabolism of a Nongrowth Substrate: L-Serine Utilization by Corynebacterium glutamicum. Applied and Environmental Microbiology 70: 7148-7155.

Oyarzún CE, R Godoy, A Sepúlveda. 1998. Water and nutrient fluxes in a cool temperate rainforest at the Cordillera de la Costa in southern Chile. Hydrological Processes 12: 10671077.

Scapini MC, V Conzonno, V Balzaretti, A Fernández Cirelli. 
2008. Propiedades ópticas del ácido fúlvico del Río Chubut. In Galantini JA, L Suñer, MR Landriscini, JO Iglesias eds. Estudio de las fracciones orgánicas en suelos de la Argentina. Bahía Blanca, Argentina. EdiUNS. p. 233-245.

Scapini MC, V Conzonno, JD Orfila, J Saravia, V Balzaretti, A Fernández Cirelli. 2011. Limnological aspects of humic substances in Chubut River (Patagonia-Argentina). River Research and Applications 27: 1264-1269.

Schlesinger WH. 1997. Biogeochemistry: an analysis of global change. 2nd ed. London, UK. Academic Press. 443 p.
Stevenson FJ. 1982. Humus Chemistry: Genesis, Composition, Reactions. New York, United States. John Wiley \& Sons. 443 p.

Tesón N. 2012. Balance hidrológico y flujo de nutrients en plantaciones de Eucalyptus grandis, en Concordia, Entre Ríos. Tesis Doctoral en Ciencias Naturales. La Plata, Argentina. Facultad de Ciencias Naturales y Museo, Universidad Nacional de La Plata. $171 \mathrm{p}$.

$\mathrm{Xu}$ X, Q Wang, E Hirata. 2005. Precipitation partitioning and related nutrient fluxes in a subtropical forest in Okinawa, Japan. Annals of Forest Science 62: 245-252.

Recibido: 26.09 .13

Aceptado: 01.08.14 